\title{
The Impact of Training on Job Performance at General Directorate of Residency and Foreigners Affairs in the U.A.E
}

\author{
Rashid Ali Al Ali, Rosman MD Yusoff, Fadillah Binti Ismail, Adnan Ali Alhisani
}

\begin{abstract}
Today, organizations are facing challenges related to the job performance. Training is being considered an important factor through which job performance and be increased. This study determines the relationship between training and job performance. For this the survey is conducted at the GDRFA (General Directorate of Residency and Foreigners Affairs) in the UAE. The number of respondents for this study was 387. A quantitative methodology was used to analyze the collected data from the respondents using standard statistical methods with the help of SPSS. The data analysis methods include descriptive statistics, reliability test, Pearson non-directional correlations and Simple Linear regression. The result of this study indicates that training is correlated with employees' productivity and job performance in a positive, moderate, and causal relationship. The weak job performance is result of unsuitable training programs that leads to poor outcomes from employees at the end of the training. This outcome shows the importance of training on developing the overall performance of employees and improving their productivity in work. Thus, training is an important factor that could enhance the job performance.
\end{abstract}

\section{Index Terms: GDRFA, U.A.E, Job Performance, Training}

\section{INTRODUCTION}

This study determines the concepts of training and job performance. Training is the process of teaching, developing the skills and knowledge of individuals that relate to particular useful competencies. Training is a useful practice that has specific objectives of improving individuals' capability, learning ability, performance and productivity (Trevisani, 2016). The principles of training come from the center of preparations and provide the pillar of development in modern organizations (Sultana et al., 2012). Today, most organizations need continuous development through continuous training to maintain the skills and knowledge of employees by continuous upgrading throughout their working life (Lindström, 2013). Training is an essential factor adopted by modern organizations and directly affects job performance

Revised Manuscript Received on September 22, 2019

Rashid Ali Al Ali, Faculty of Technology Management, Universiti Tun Hussein Onn Malaysia, 86400 Parit Raja, Batu Pahat, Johor, Malaysia. rashed_alalili@hotmail.com

Rosman MD Yusoff, Centre for General Studies and Co-Curricular, Univeristi Tun Hussein Onn Malaysia, 86400 Parit Raja, Batu Pahat, Johor, Malaysia.rosmanmy@uthm.edu.my

Fadillah Binti Ismail, Faculty of Technology Management, Universiti Tun Hussein Onn Malaysia, 86400 Parit Raja, Batu Pahat, Johor, Malaysia. fadillah@uthm.edu.my

Adnan Ali Alhisani, Faculty of Technology Management, Universiti Tun Hussein Onn Malaysia, 86400 Parit Raja, Batu Pahat, Johor, Malaysia. dnanvip@hotmail.com. and the productivity of the organization. Most studies in the field of development and quality showed that training had become a crucial part of the human resource strategies for development staff skills and knowledge in business organizations, where government agencies can only achieve a high level of productivity through personnel training and providing the necessary resources for training programs (Al-Tarawneh, 2012). The contributions of training are significant in achieving the objectives and strategies of most organizations in today's business world. On the other hand, the changes expected to happen to the productivity of the organization after training could lead to more revenue and improve the service and products of the organization in the long-term. As such, regulatory development through training is particularly important in the business sector. This can be done by "increasing individual needs to update their skills and acquire new skills through a well thought out training programs in accordance with the latest theories and scientific methods" (Rawyah, 2005). "Training has a distinct role in the achievement of an organizational goal by incorporating the interests of the organization and the workforce" (Stone, 2006). Nowadays training in the UAE is the most critical factor to increase the employees' performance in organizations because it enhances the capabilities of employees in public companies at the UAE. "The employees who have more experience in their job have better performance because there is an increase in both skills and competencies because of more on-the-job experience" (Fakhar and Anwar, 2008). "Most organizations do not have adequate information on the nature of the training theories and how to use the proper training programs that match the type of business or work" (Tomblin and Haring, 2000).

This study is an attempt to discuss the effect of training on the job performance in the GDRFA in the UAE. The purpose of this study is to examine the relationship between training and job performance in the UAE public organizations

\section{LITERATURE REVIEW}

\section{A. Training}

Training is an independent variable in this study. Previous studies defined it as "the method that contributes to achieving significant changes in employees' performance and productive" (Hill and Lent 2006, Satterfield and Hughes 2007; Kraiger 2002). 
Training is a set of activities have embarked upon by organizations that leads to knowledge and skills acquisition in order to achieve growth. That way, "it contributes to the well-being and performance of the human capital, organization and the whole society" (Khawaja \& Nadeem, 2013).

Kirkpatrick \& Kirkpatrick (2013) have written articles on the evaluations of training programs. These articles have been published in 1994 and were used to establish the original ideas published in 1959 as the famous theory of training evaluation. The model is applied to maximize and demonstrate the value of training to the organization (before, during, and after training). This determines training through the reaction (The participants' opinion about training, its way of conduct, and the relevance to their job), learning (how much the participants acquire knowledge, skills, attitude, confidence and scenes of commitment), and behavior (The change in employees' attitude and performance after getting training). This study is based on the Kirkpatrick model.

\section{B. Job Performance}

Some scholars suggested that job performance represents the description of the expectations from an employee and indicates the level of employee's skills and knowledge about his/her (Abbas and Yaqoob, 2009; Kahya, 2009; Osunde, 2015). Job performance is essential for organizational outcomes and profitability this defines how well employees perform their jobs. Abbas and Yaqoob (2009) mention that "Organizations should focus on the factors which improve the performance of the employee" as it is a significant component of any organization". Employees' performance is crucial because it leads the organization to success. This is common perception that the satisfied employees perform better than the unsatisfied employees. Many companies assess their employees' performance annually or quarterly. This helps them to identify the areas for improvement. Kinicki and Kreitner (2006) reveals that "Performance is a critical factor in organizational success". Employee performance can be measured in various ways "like productivity, absenteeism, and employee satisfaction" (Osunde, 2015).

This study presented three dimensions to measure job performance, 1) task performance, refers to "the proficiency with which central job tasks are performed" (Beaton et al., 2009); 2) contextual performance, refers to "behaviors that support the organizational, social, and psychological environment in which the technical core must function" (Maxham et al., 2008); and 3) adaptive performance is included in the heuristic framework. Three reasons support the inclusion of adaptive performance, referring to "an employee's ability to adapt to changes in a working system or work roles" (Griffin et al., 2007).

\section{Relationship between Training and Job performance}

Employees join the training program with many expectations, and when these expectations are not accomplished, this will result in high employee turnover and low commitment. Low commitment will push the employees to leave the organization (Brum, 2007). Organizations all over the world are more concerned about their employees. Thus, they provide various training programs and activities

for value creation of their employees. Global organizations train their employees in practical aspects. "Training not only improves the mental abilities of employees but also after training, employees could benefit physically such as actively participating in the decision-making process" (Farooq \& Khan, 2011). Training is helpful to build understanding among employees and senior management. It also qualifies the employee to take part in decision-making and offer effective output in decision-making. Training plays a key role in increasing employee coordination with colleagues, subordinates and with the senior managers (Naqvi, 2013). Training boosts employees' initiative and the quality of work, herewith "encouraging them to be more committed to achieving the organizational objectives and goals and in turn promoting the employees' efficiency in the organization" (Nda Maimuna and Rashad, 2013).

Previous studies discussed in this section are evident that training affects the job performance of employees in a direct and causal relationship. Therefore, the study will test the following hypothesis:

H1: There is positive relationship between training and job performance.

\section{METHODOLOGY}

This study is conducted in the UAE. The survey was performed in the GDRFA in UAE. The study population consisted of 5881 individuals comprising employees, staff, and managers in GDRFA. The sample of this study was determined by using Yamane (1967). The sample size using the formula provided by Yamane (1967), which is depicted as follows,

$$
\begin{aligned}
& \eta=\frac{\mathrm{N}}{1+\mathrm{N} \mathrm{e}^{2}} \\
& \text { Where, } \\
& \eta=\text { sample size } \\
& \mathrm{N}=\text { the population of the study } \\
& \mathrm{e}=\text { the level of significance (set at } 0.05 \text { for this study) }
\end{aligned}
$$

To determine the sample size of this study, the following formula is used:

$$
\begin{aligned}
& \eta=\frac{5881}{1+5881 \times 0.05^{2}} \\
& \eta=\frac{5881}{1+5881 \times 0.0025} \\
& \eta=\frac{5881}{1+14.702} \\
& \eta=375
\end{aligned}
$$

The researcher increased the sample size from 375 to 387 in order to increase the reliability of data instrument. A quantitative methodology was used to analyze the collected data from the respondents using standard statistical methods with the help of SPSS. The data analysis methods include descriptive statistics, reliability test, Pearson non-directional correlations and Simple Linear regression 


\section{RESULTS AND DISCUSSION}

\section{A. Gender}

Table 1 shows the number of male and female participants in the survey at GDRFA in UAE; the percentage of male $(69.80 \%)$ is greater than the percentage of female $(30.20 \%)$.

TABLE1: FREQUENCIES OF GENDER DEMOGRAPHIC FACTOR

\begin{tabular}{llllll}
\hline & & \multirow{2}{*}{ Frequency } & Percent & $\begin{array}{l}\text { Valid } \\
\text { Percent }\end{array}$ & $\begin{array}{l}\text { Cumulative } \\
\text { Percent }\end{array}$ \\
\hline \multirow{3}{*}{ Valid } & Male & 270 & 69.8 & 69.8 & 69.8 \\
& Female & 117 & 30.2 & 30.2 & 100.0 \\
& Total & 387 & 100.0 & 100.0 & \\
\hline
\end{tabular}

\section{B. Work Experience}

Table 2 shows the distribution of work experience in the General Directorate of Residency and Foreigners Affairs in the UAE (GDRFA). It is evident that the frequencies and percentages level of work experience decreased gradually from minimum to maximum. The maximum percentage is scored those who have experience in work (1-5) years; those represent $39.8 \%$ from the total percentage, the next are those who have experience in work between 6-10 years $(33.10 \%$ middle experience). In other words, the majority of employees in this organization have low experience, where those who have very long experience in work (>16 years) are minimum $=9.00 \%$

TABLE2: WORK EXPERIENCE IN THE GENERAL DIRECTORATE OF RESIDENCY AND FOREIGNERS AFFAIRS IN THE UAE (GDRFA)

\begin{tabular}{|c|c|c|c|c|c|}
\hline & & Frequency & Percent & $\begin{array}{l}\text { Valid } \\
\text { Percent }\end{array}$ & $\begin{array}{l}\text { Cumulative } \\
\text { Percent }\end{array}$ \\
\hline \multirow{5}{*}{$\begin{array}{l}\text { Vali } \\
\text { d }\end{array}$} & $\begin{array}{l}1-5 \\
\text { years }\end{array}$ & 154 & 39.8 & 39.8 & 39.8 \\
\hline & $\begin{array}{l}6-10 \\
\text { years }\end{array}$ & 128 & 33.1 & 33.1 & 72.9 \\
\hline & $\begin{array}{l}11-15 \\
\text { years }\end{array}$ & 70 & 18.1 & 18.1 & 91.0 \\
\hline & $\begin{array}{l}16-20 \\
\text { years }\end{array}$ & 35 & 9.0 & 9.0 & 100.0 \\
\hline & Total & 387 & 100.0 & 100.0 & \\
\hline
\end{tabular}

\section{Reliability Test}

The reliability coefficient is used to measure the internal consistency of the questionnaire designed for the survey. The reliability coefficient is mainly utilized to measure the amount of measurement error associated with a Chronbach's test score. The acceptable value for the coefficient of reliability, ranges between 0 (Zero) and 1(one). The Table 3 shows the realiability analysis.

TABlE3: RELIABILITY ANALYSIS (CRONBACH'S ALPHA OF TRAINING AND JOB PERFORMANCE)

\begin{tabular}{lll}
\hline Variable name & $\begin{array}{l}\text { Reliability Coefficient } \\
\text { (Cronbach's Alpha) }\end{array}$ & $\begin{array}{l}\text { Reliability } \\
\text { level }\end{array}$ \\
\hline $\begin{array}{l}\text { Training } \\
\begin{array}{l}\text { Job } \\
\text { performance }\end{array}\end{array}$ & 0.826 & Very Good \\
\hline
\end{tabular}

\section{Pearson Correlation Analysis}

The output of the correlation matrix in Table 4 shows that correlations between the independent variable training and the dependent variable job performance. Pearson correlation between training and job performance $r=0.390$, statistically significant and positive.

TABle 4: PEARSON CORRELATION MATRIX BETWEEN TRAINING AND JOB PERFORMANCE

\begin{tabular}{llll}
\hline & & Training & Performance \\
\hline \multirow{4}{*}{ Training } & Pearson & 1 & $.390^{* *}$ \\
& Correlation & & .000 \\
& Sig. (2-tailed) & & 387 \\
& $\mathrm{~N}$ & 387 & 1 \\
\multirow{5}{*}{ Performance } & Pearson & $.390^{* *}$ & \\
& Correlation & & \\
& Sig. (2-tailed) & .000 & 387 \\
\hline
\end{tabular}

**. Correlation is significant at the 0.01 level (2-tailed).

Linear Regression between Training and Job performance

The results of the regression between training and job performance are shown in the three outputs tables (models summary table, ANOVA table, and Coefficients table).

\section{E. The Model Summary of Simple Linear Regression}

The model summary provides initial information about the regression strength between training and job performance. Table 5 identifies the simple correlation coefficient $(\mathrm{R})$, the coefficient of determination $\left(\mathrm{R}^{2}\right)$, and the adjusted R-Square.

TABLE 5: MOdel SUMMARY OF SIMPLE LINEAR REGRESSION OUTPUT BETWEEN TRAINING AND JOB PERFORMANCE.

\begin{tabular}{lllll}
\hline $\begin{array}{l}\text { Mode } \\
1\end{array}$ & $\mathrm{R}$ & R-Square & $\begin{array}{l}\text { Adjusted } \\
\text { R-Square }\end{array}$ & $\begin{array}{l}\text { Std. Error of } \\
\text { the Estimate }\end{array}$ \\
\hline 1 & $.390^{\mathrm{a}}$ & .152 & .150 & .55970
\end{tabular}

a. Predictors: (Constant), Training

b. Dependent Variable: Job Performance

Reading the values in model summary enables the researcher to know how well the regression model predicts the observation of the variance and variability between the two variables. It is found that $R$ (simple linear correlation) $=$ 0.390 , this result indicates a good degree of association between training and job performance. The $\mathrm{R}^{2}$ indicates how much of the total variation in the job performance can be explained by training. $\mathrm{R}^{2}=0.152$ indicates that $(15.20 \%)$ of the variance in job performance is explained by the variance in training. Thus, the change in job performance is $15.20 \%$ could be predicted by training. The remaining of the variance in job performance $=84.80$ is presumed to be due to random variability not related to training. The adjusted R-squared adjusted $15.00 \%$ of the variance between training and job performance, where this value indicates a very small difference (0.002) between adjusted R-squared and Predicted $\mathrm{R}^{2}$ obtained from the regression output which is statistically accepted. It should be noted that if $R^{2}$ and the adjusted $R^{2}$ having a large difference, then it shows a bad output, which indicates the level of fit of the regression model is not acceptable as well as the fit of the regression equation between the independent and dependent variable.

\section{F. ANOVA Output}

Table 6 in regression outputs reports how well the regression equation fits the data (i.e., predicts the dependent variable). 
TABLE 6: ANOVA OUTPUT

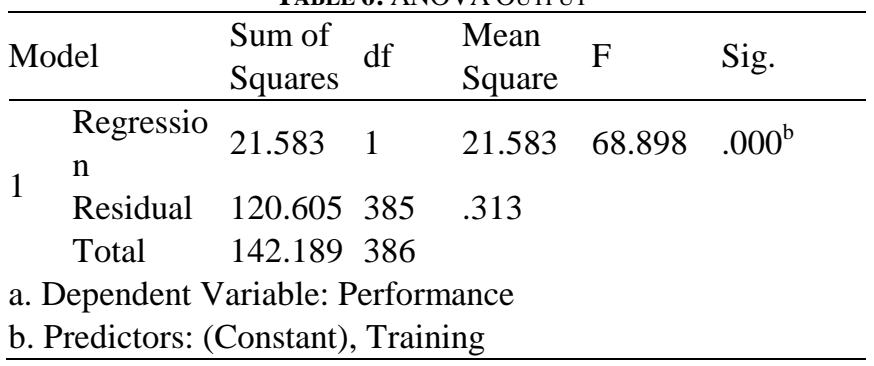

The inspection of the output table of ANOVA reveals the fit of the correlation between training and job performance and whether this correlation is statistically significant. As mentioned before, the conclusion about the fit is made through comparing the $\rho$-value in the table below with the standard significance level $(\rho \leq 0.05)$. The last column in the below table shows that $(\rho=0.000)$, then the study accept the hypothesis H1. Therefore, the regression model predicts the dependent variable significantly well. In other words, the overall regression model statistically significantly predicts the outcome variable Job performance (i.e., the output of regression is a good fit for the data).

The F-Value and its significance level in regression analysis shows the output. If the F-value is statistically significant (typically $\mathrm{p}<.05$ ), this shows that there is a significant relationship between the predictor and the dependent variable. The value of $F=68.898>1.00$. Thus the variation between the means of two variables is not by chance. In other words, there is a causal relationship between training and job performance. According to that, the hypothesis (H1) is true.

\section{G. The Regression Coefficients}

Table 7 the coefficients of regression provides the necessary information to predict job performance from training. Also, it is helpful to determine whether training contributes significantly to the regression model.

TABLE 7: COEFFICIENTS

\begin{tabular}{|c|c|c|c|c|}
\hline \multirow{3}{*}{ Model } & Unsta & ardized & Standardize & \\
\hline & \multicolumn{2}{|c|}{ Coefficients } & Coefficients & Sig. \\
\hline & B & $\begin{array}{l}\text { Std. } \\
\text { Error }\end{array}$ & Beta & Nig. \\
\hline \multirow{2}{*}{1 Trai } & 1.876 & .154 & & 12.195 .000 \\
\hline & .376 & .045 & .390 & $\begin{array}{ll}8.301 \quad .000\end{array}$ \\
\hline
\end{tabular}

a. Dependent Variable: Performance

Reading the level of significance in the last column (Table

7) shows that the regression equation is statistically significant $(\rho<=0.01)$. Also, the unstandardized coefficient (B) is positive and moderate $\mathrm{B}=0.376$. Thus, it is concluded that the change in training positively predicts job performance. According to that, it is found that $\mathrm{H} 1$ is true and is accepted.

\section{CONCLUSION}

This study concludes that training is a continuous development process lead to the acquisition of new skills; knowledge, and improving the capability of employees to deal with complex tasks and handle a difficult situation in work, also and improve the employees' behavior within organization. Training is an important variable in the success of the organization this is consist of learning, reaction, and behavior.

The reaction of the respondents showed that they were satisfied with the training. They agreed that the place of training was suitable for the implementation of the training program, and training supplies were sufficient during the training. The trainer was responsive to the questions and satisfied the respondent with answers. With regard to the second-factor learning, it is evident that the work performance of employees improved due to the development of my knowledge after the training, but employees were not certain whether they need more courses to develop their information on the work. One of the negative points found in the survey is that the center of training does not test the effectiveness of learning through training by monitoring the evolution of work performance; there is no training evaluation after ending the training program. After training, employees confirmed they had developed their skills in doing the work. Finally, the the results of behavior analysis shows that employees' confidence has been increased to perform tasks and relationship among employees strengthened. Thus, this can be concluded that with training, job performance can be improved.

\section{REFERENCES:}

[1] Abbas, Q., \& Yaqoob, S. (2009). Effect of leadership development on employee performance in Pakistan. Pakistan Economic and Social Review, 47(2), 269-292.

[2] Al-Tarawneh. Tahseen Ahmed. (2012). Commitment to apply and impact of training stages in the areas of performance of employees. Arab Journal of Security Studies and Training.26(5).

[3] Beaton, D., Bombardier, C., Escorpizo, R., Zhang, W., Lacaille, D. Boonen, A., ... \& Tugwell, P. S. (2009). Measuring worker productivity: frameworks and measures. The Journal of rheumatology, 36(9), 2100-2109.

[4] Brum, S. (2007). What impact does training have on employee commitment and employee turnover?.

[5] Farooq, M., \& Khan, M. A. (2011). Impact of training and feedback on employee performance. Far east journal of psychology and business, 5(1), 23-33.

[6] Fakhar, U. F., \& Anwan, K. (2008). Case of Pearl continental hotels in Pakistan, relationship training with employees performance in Hoteling Industry.

[7] Griffin, M. A., Neal, A., \& Parker, S. K. (2007). A new model of work role performance: Positive behavior in uncertain and interdependent contexts. Academy of management journal, 50(2), 327-347.

[8] Kahya, E. (2009). The effects of job performance on effectiveness. International Journal of Industrial Ergonomics, 39(1), 96-104.

[9] Kirkpatrick, D., \& Kirkpatrick, J. (2013). KIRKPATRICK FOUR LEVELS.

[10] Kinicki, A., \& Kreitner, R. (2006). Organizational behavior: Key concepts, skills \& best practices. New York: McGraw-Hill/Irwin.

[11] Lindström, S., \& Vanhala, S. (2013). Performance in local government HRM: the role of external customers. Baltic Journal of Management, $8(3), 252-268$.

[12] Maxham III, J. G., Netemeyer, R. G., \& Lichtenstein, D. R. (2008). The retail value chain: linking employee perceptions to employee performance, customer evaluations, and store performance. Marketing Science, 27(2), 147-167.

[13] Naqvi, S. M. H., \& Khan, M. A. (2013). Employees training and organizational performance: Mediation by employees performance. Interdisciplinary Journal Of Contemporary Research In Business Copy, 5(4).

[14] Nda, M. M., \& Fard, R. Y. (2013). The impact of employee training and development on employee productivity. Global Journal of commerce and management perspective, 2(6), 91-93. 
[15] Osunde, C. (2015). Privatization of Public Enterprises in Nigeria: Impact on employees' performance and managerial implications. International Journal Of Research-Grant Haalayah A Knowledge Repository, 3(3).

[16] Trevisani, D. (2016). Communication for leadership: Coaching leadership skills. Medialab Research, Ferrara.

[17] Rawyah Hassan. (2005). strategic entrance to the planning and development of human resources. University House. Amman. Jordan

[18] Stone, D. L., Stone-Romero, E. F., \& Lukaszewski, K. (2006). Factors affecting the acceptance and effectiveness of electronic human resource systems. Human Resource Management Review, 16(2), 229-244.

[19] Sultana, A., Irum, S., Ahmed, K., \& Mehmood, N. (2012). Impact of training on employee performance: A study of telecommunication sector in Pakistan. Interdisciplinary Journal of contemporary research in business, 4(6), 646-661.

[20] Tomblin, M., \& Haring, K. A. (2000). Performance of job-related skill training for young people with disabilities. Journal of vocational education and training, 52(2), 295-305.

\section{AUTHORS PROFILE}

Rashid Ali Al Ali, Faculty of Technology Management, Universiti Tun Hussein Onn Malaysia, 86400 Parit Raja, Batu Pahat, Johor, Malaysia. rashed_alalili@hotmail.com

Rosman MD Yusoff, Centre for General Studies and Co-Curricular, Univeristi Tun Hussein Onn Malaysia, 86400 Parit Raja, Batu Pahat, Johor, Malaysia.rosmanmy@uthm.edu.my

Fadillah Binti Ismail, Faculty of Technology Management, Universiti Tun Hussein Onn Malaysia, 86400 Parit Raja, Batu Pahat, Johor, Malaysia. fadillah@uthm.edu.my

Adnan Ali Alhisani, Faculty of Technology Management, Universiti Tun Hussein Onn Malaysia, 86400 Parit Raja, Batu Pahat, Johor, Malaysia. dnanvip@hotmail.com. 